\title{
Training Needs of Goat Entrepreneurs in Tamil Nadu
}

\author{
Sireesha Pulla ${ }^{*}$, R. Nithiaselvi ${ }^{2}$, P. Mathialagan ${ }^{1}$ and P. Thilakar ${ }^{1}$ \\ ${ }^{1}$ Department of Veterinary \& A.H Extension Education \\ ${ }^{2}$ Department of Animal Genetics \& Breeding, Madras Veterinary College, TamilNadu \\ Veterinary \& Animal Sciences University (TANUVAS), Chennai- 600007, India \\ *Corresponding author
}

\section{A B S T R A C T}

The study was conducted on the entrepreneurs interested in goat farming in the state of Tamil Nadu.The training needs of the selected goat entrepreneurs were assessed in six major areas viz. management, breeding,

\section{Keywords}

Training needs, Goat entrepreneurs, Training Need Index

Article Info

Accepted:

15 December 2019 Available Online: 20 January 2020 feeding, housing, health care and marketing and record keeping. The study revealed that in the area of Goat care and management, Care and management of kid was perceived to be the most important training need followed by Housing system and its cleaning. With respect to feeding management, maximum training need was expressed about feeding of pregnant does and its importance followed by feeding of buck and its importance. Practices for increasing twinning and triplets percentage was the most needed training sub area in the area of breeding management. Most needed training sub area reported by goat entrepreneurs were information about disease and prevention and destruction of internal and external parasites and its importance in disease and health care management. Training on tools for profitable goat farming was the most needed training sub area in the area of marketing and record keeping.

\section{Introduction}

Goat farming is one of the various important livestock enterprises which supports the rural households by providing employment and steady income for the rural masses. India is among the highest small ruminants holding countries in the world having 15 per cent of world's goat and 6 per cent of sheep (SA
PPLPP, 2011)and goat is considered as 'poor man's cow' and 'mobile bank', as goat enterprise needs less inputs and yields high rates of return. In this context, small ruminants especially goat has a tremendous potential to be projected as 'future animal' for both rural and urban India (CIRG, 2011). Goat production in India has low productivity per se which may be attributed to various 
factors like shortage of feed and fodder, lack of scientific knowledge, rearing non-descript breeds, low fertility etc. which are also considered to be the major constraints of goat farming (Landge, 2004). It is observed that, there is a gap between management practices followed by the farmers and the available scientific technologies. Hence, need based training programmes are very essential for transfer of technologies at field conditions. Identifying training needs involves establishing areas where individuals lack skills, knowledge and ability in effectively performing the operations and also identifying organizational constraints that are creating road blocks in the performance (Mirza, 2005). With this background, the present study was conducted to analyse the training needs of the goat entrepreneurs.

\section{Materials and Methods}

The present study was conducted on the entrepreneurs interested in goat farming in the state of TamilNadu. A questionnaire was developed in consultation with experts and relevant literature. The training needs of the selected goat entrepreneurs were assessed in six major areas viz. management, breeding, feeding, housing, health care and marketing \& record keeping. Further, major areas were sub divided into various minor areas and training needs of the goat entrepreneurs were retrieved by using three point scale viz. Most needed, Needed and Least Needed.

\section{Option (Response category) Score}

Most Needed $(\mathrm{MN})=3$

Needed $(\mathrm{N})=2$

Least Needed $(\mathrm{LN})=1$

Weighted Score $(\mathrm{WS})=($ No. of $\mathrm{MN} \times 3)+$ $($ No. of $\mathrm{N} \times 2)+($ No. of $\mathrm{LN} \times 1)$

The Training Need Index (TNI) was computed with the help of following formula (Patil and Kokate, 2011).

\section{Training Need Index =}

Total Obtained Score $\times 100$

Maximum Obtainable Score

The collected data were scored, tabulated, and analysed by using frequency, percentage, weighted mean and ranking.

\section{Results and Discussion}

Among the respondents who attended the training, majority $(93.33 \%)$ were male and the rest were female $(6.67 \%)$.

Majority of them $(56.67 \%)$ belong to middle age followed by young (23.33\%) and middle age $(20 \%)$.

It is evident from Table 3 that Care and management of kid (TNI $=96.67)$ was the most important training area followed by Housing system and its cleaning $(\mathrm{TNI}=$ 94.44), care of does before, after and at the time of kidding, methods of goat rearing and its importance $(\mathrm{TNI}=93.33)$, importance of colostrum $(\mathrm{TNI}=90.00)$, castration of kid for sale and its importance, breeds of goats and its importance $(\mathrm{TNI}=87.73)$ and care and management of milking does $(\mathrm{TNI}=86.67)$ respectively. Care and management of kids was given first rank because mortality of young ones can be reduced by adopting scientific management practices and regular replacement stock of flock which tends to increase the profitability of enterprise. These findings are not in line with Tekale (2013).

Table 4 depicted that among various practices in feeding management, feeding of does and pregnant does and its importance $(\mathrm{TNI}=$ 97.78) was ranked first followed by feeding of buck and its importance (TNI $=95.56)$, care about feeding of does before and after kidding $(\mathrm{TNI}=94.44)$, importance of mineral mixture in feeding (TNI $=93.33$ ), feeding of kids and its importance, fodder production for goat and its importance, storage of fodder and its benefits, enrichment of poor quality 
roughages $(\mathrm{TNI}=92.22)$ respectively. Similar findings were reported by Jena (2018).Sound feeding management at important stages provides effective way to improve the productivity of farm and also the number of offsprings born.

Table 5 revealed that majority of the respondents felt practices for increasing twinning and triplets percentage (TNI = 96.67), followed by selection and its importance of male and female goat for breeding, flushing procedure for synchronization of estrus $($ TNI $=95.56)$, methods of breeding for improving the good genetic potentiality $(\mathrm{TNI}=94.44)$. These findings are in conformity to the observation found by Jena (2018). The probable reason behind this result might be due to the fact that higher returns are possible with twins and triplets born in the flock.

Table.1 Distribution of respondents according to gender

\begin{tabular}{|c|c|c|c|}
\hline S.No. & Gender & Frequency & Percentage \\
\hline 1. & Male & 28 & 93.33 \\
\hline 2. & Female & 02 & 6.67 \\
\hline
\end{tabular}

Table.2 Distribution of respondents according to age

\begin{tabular}{|l|l|c|c|}
\hline S.No. & \multicolumn{1}{|c|}{ Category } & Frequency & Percentage \\
\hline 1. & Young age $(<35$ years $)$ & 07 & 23.33 \\
\hline 2. & Middle age $(35-50$ years $)$ & 17 & 56.67 \\
\hline 3. & Old age $(>50$ years $)$ & 06 & 20 \\
\hline
\end{tabular}

Table. 3 Training needs in Goat care and Management

\begin{tabular}{|r|l|c|c|c|c|c|c|}
\hline S.No. & \multicolumn{1}{|c|}{ Training areas } & $\begin{array}{c}\text { Most } \\
\text { Needed }\end{array}$ & Needed & $\begin{array}{c}\text { Weighted } \\
\text { mean score }\end{array}$ & $\begin{array}{c}\text { Mean } \\
\text { score }\end{array}$ & TNI & Rank \\
\hline $\mathbf{1 .}$ & $\begin{array}{l}\text { Methods of goat rearing } \\
\text { and its importance }\end{array}$ & $\begin{array}{c}24 \\
(80 \%)\end{array}$ & $\begin{array}{c}06 \\
(20 \%)\end{array}$ & 84.00 & 2.80 & 93.33 & III \\
\hline $\mathbf{2 .}$ & $\begin{array}{l}\text { Breeds of goat and its } \\
\text { importance }\end{array}$ & $\begin{array}{c}19 \\
(63.33 \%)\end{array}$ & $\begin{array}{c}11 \\
(36.67 \%)\end{array}$ & 79.00 & 2.63 & 87.78 & V \\
\hline $\mathbf{3 .}$ & $\begin{array}{l}\text { Care of does before, after } \\
\text { and at the time of kidding }\end{array}$ & $\begin{array}{c}24 \\
(80 \%)\end{array}$ & $\begin{array}{c}06 \\
(20 \%)\end{array}$ & 84.00 & 2.80 & 93.33 & III \\
\hline $\mathbf{4 .}$ & $\begin{array}{l}\text { Care and management of } \\
\text { kid }\end{array}$ & $\begin{array}{c}27 \\
(90 \%)\end{array}$ & $\begin{array}{c}03 \\
(10 \%)\end{array}$ & 87.00 & 2.90 & 96.67 & I \\
\hline $\mathbf{5 .}$ & Importance of colostrum & $\begin{array}{c}21 \\
(70 \%)\end{array}$ & $\begin{array}{c}09 \\
(30 \%)\end{array}$ & 81.00 & 2.70 & 90.00 & IV \\
\hline $\mathbf{6 .}$ & $\begin{array}{l}\text { Care and management of } \\
\text { milking does }\end{array}$ & $\begin{array}{c}18 \\
(60 \%)\end{array}$ & $\begin{array}{c}12 \\
(40 \%)\end{array}$ & 78.00 & 2.60 & 86.67 & VI \\
\hline $\mathbf{7 .}$ & $\begin{array}{l}\text { Castration of kid for sale } \\
\text { and its importance }\end{array}$ & $\begin{array}{c}19 \\
(63.33 \%)\end{array}$ & $\begin{array}{c}11 \\
(36.67 \%)\end{array}$ & 79.00 & 2.63 & 87.78 & V \\
\hline $\mathbf{8 .}$ & $\begin{array}{l}\text { Housing system and its } \\
\text { cleaning }\end{array}$ & $\begin{array}{c}25 \\
(83.33 \%)\end{array}$ & $\begin{array}{c}05 \\
(16.67 \%)\end{array}$ & 85.00 & 2.83 & 94.44 & II \\
\hline
\end{tabular}


Table.4 Training needs in Feeding Management

\begin{tabular}{|c|c|c|c|c|c|c|c|}
\hline S.No. & Training areas & $\begin{array}{c}\text { Most } \\
\text { Needed }\end{array}$ & Needed & $\begin{array}{l}\text { Weighted } \\
\text { mean score }\end{array}$ & $\begin{array}{l}\text { Mean } \\
\text { score }\end{array}$ & TNI & Rank \\
\hline 1. & $\begin{array}{l}\text { Feeding of pregnant } \\
\text { does and its } \\
\text { importance }\end{array}$ & $\begin{array}{c}28 \\
(93.33 \%)\end{array}$ & $\begin{array}{c}02 \\
(6.67 \%)\end{array}$ & 88.00 & 2.93 & 97.78 & I \\
\hline 2. & $\begin{array}{l}\text { Care about feeding of } \\
\text { does before and after } \\
\text { kidding }\end{array}$ & $\begin{array}{c}25 \\
(83.33 \%)\end{array}$ & $\begin{array}{c}05 \\
(16.67 \%)\end{array}$ & 85.00 & 2.83 & 94.44 & III \\
\hline 3. & $\begin{array}{l}\text { Feeding of kids and } \\
\text { its importance }\end{array}$ & $\begin{array}{c}23 \\
(76.67 \%)\end{array}$ & $\begin{array}{c}07 \\
(23.33 \%)\end{array}$ & 83.00 & 2.77 & 92.22 & $\mathrm{~V}$ \\
\hline 4. & $\begin{array}{l}\text { Feeding of buck and } \\
\text { its importance }\end{array}$ & $\begin{array}{c}26 \\
(86.67 \%)\end{array}$ & $\begin{array}{c}04 \\
(13.33 \%)\end{array}$ & 86.00 & 2.87 & 95.56 & II \\
\hline 5. & $\begin{array}{l}\text { Fodder production for } \\
\text { goat and its } \\
\text { importance }\end{array}$ & $\begin{array}{c}23 \\
(76.67 \%)\end{array}$ & $\begin{array}{c}07 \\
(23.33 \%)\end{array}$ & 83.00 & 2.77 & 92.22 & $\mathrm{~V}$ \\
\hline 6. & $\begin{array}{l}\text { Storage of fodder and } \\
\text { its benefits }\end{array}$ & $\begin{array}{c}23 \\
(76.67 \%)\end{array}$ & $\begin{array}{c}07 \\
(23.33 \%)\end{array}$ & 83.00 & 2.77 & 92.22 & V \\
\hline 7. & $\begin{array}{l}\text { Enrichment of poor } \\
\text { quality roughages }\end{array}$ & $\begin{array}{c}23 \\
(76.67 \%)\end{array}$ & $\begin{array}{c}07 \\
(23.33 \%)\end{array}$ & 83.00 & 2.77 & 92.22 & $\mathrm{~V}$ \\
\hline 8. & $\begin{array}{ll}\text { Importance } & \text { of } \\
\text { mineral mixture in } \\
\text { feeding }\end{array}$ & $\begin{array}{c}24 \\
(80 \%)\end{array}$ & $\begin{array}{c}06 \\
(20 \%)\end{array}$ & 84.00 & 2.80 & 93.33 & IV \\
\hline
\end{tabular}

Table.5 Training needs in Breeding Management

\begin{tabular}{|c|l|c|c|c|c|c|c|}
\hline S.No. & \multicolumn{1}{|c|}{ Training areas } & $\begin{array}{c}\text { Most } \\
\text { Needed }\end{array}$ & Needed & $\begin{array}{c}\text { Weighted } \\
\text { mean } \\
\text { score }\end{array}$ & $\begin{array}{c}\text { Mean } \\
\text { score }\end{array}$ & TNI & Rank \\
\hline $\mathbf{1 .}$ & $\begin{array}{l}\text { Selection and its } \\
\text { importance of male and } \\
\text { female goat for breeding }\end{array}$ & $\begin{array}{c}26 \\
(86.67 \%)\end{array}$ & $\begin{array}{c}04 \\
(13.33 \%)\end{array}$ & 86.00 & 2.87 & 95.56 & II \\
\hline $\mathbf{2 .}$ & $\begin{array}{l}\text { Practices for increasing } \\
\text { twinning and triplets } \\
\text { percentage }\end{array}$ & $\begin{array}{c}27 \\
(90 \%)\end{array}$ & $\begin{array}{c}03 \\
(10 \%)\end{array}$ & 87.00 & 2.90 & 96.67 & I \\
\hline $\mathbf{3 .}$ & $\begin{array}{l}\text { Methods of breeding for } \\
\text { improving the good } \\
\text { genetic potentiality }\end{array}$ & $\begin{array}{c}25 \\
(83.33 \%)\end{array}$ & $\begin{array}{l}05 \\
(16.67 \%)\end{array}$ & 85.00 & 2.83 & 94.44 & III \\
\hline $\mathbf{4 .}$ & $\begin{array}{l}\text { Flushing procedure for } \\
\text { synchronization of } \\
\text { oestrus }\end{array}$ & $\begin{array}{c}26 \\
(86.67 \%)\end{array}$ & $\begin{array}{c}04 \\
(13.33 \%)\end{array}$ & 86.00 & 2.87 & 95.56 & II \\
\hline
\end{tabular}


Table.6 Training needs in Disease and Health Care Management

\begin{tabular}{|c|c|c|c|c|c|c|c|}
\hline S.No. & Training areas & $\begin{array}{l}\text { Most } \\
\text { Needed }\end{array}$ & Needed & $\begin{array}{l}\text { Weighted } \\
\text { mean } \\
\text { score }\end{array}$ & $\begin{array}{l}\text { Mean } \\
\text { score }\end{array}$ & TNI & Rank \\
\hline 1. & $\begin{array}{lr}\text { Vaccination } & \text { for } \\
\text { prevention } & \text { of } \\
\text { contagious diseases } \\
\text { and its importance }\end{array}$ & $\begin{array}{c}25 \\
(83.33 \%)\end{array}$ & $\begin{array}{c}05 \\
(16.67 \%)\end{array}$ & 85.00 & 2.83 & 94.44 & III \\
\hline 2. & $\begin{array}{lrr}\text { Information } & \text { about } \\
\text { disease i.e. } & \text { mastitis, } \\
\text { ET, } & \text { BQ, } & \text { Pox, } \\
\text { pneumonia } & \end{array}$ & $\begin{array}{c}29 \\
(96.67 \%)\end{array}$ & $\begin{array}{c}01 \\
(3.33 \%)\end{array}$ & 89.00 & 2.97 & 98.89 & I \\
\hline 3. & $\begin{array}{l}\text { Information about } \\
\text { cutting of navel cord } \\
\text { and its importance }\end{array}$ & $\begin{array}{c}28 \\
(93.33 \%)\end{array}$ & $\begin{array}{c}02 \\
(6.67 \%)\end{array}$ & 88.00 & 2.93 & 97.78 & II \\
\hline 4. & $\begin{array}{l}\text { Prevention and } \\
\text { destruction of internal } \\
\text { and external parasites } \\
\text { and its importance }\end{array}$ & $\begin{array}{c}29 \\
(96.67 \%)\end{array}$ & $\begin{array}{c}01 \\
(3.33 \%)\end{array}$ & 89.00 & 2.97 & 98.89 & I \\
\hline 5. & $\begin{array}{l}\text { Diseases of goat and } \\
\text { home remedies }\end{array}$ & $\begin{array}{c}28 \\
(93.33 \%)\end{array}$ & $\begin{array}{c}02 \\
(6.67 \%)\end{array}$ & 88.00 & 2.93 & 97.78 & II \\
\hline 6. & $\begin{array}{l}\text { Ethnoveterinary } \\
\text { practices for treatment }\end{array}$ & $\begin{array}{l}24 \\
(80 \%)\end{array}$ & $\begin{array}{c}06 \\
(20 \%)\end{array}$ & 84.00 & 2.80 & 93.33 & IV \\
\hline
\end{tabular}

Table.7 Training needs in Marketing and Record Keeping

\begin{tabular}{|r|l|c|c|c|c|c|c|}
\hline S.No. & \multicolumn{1}{|c|}{ Training areas } & $\begin{array}{c}\text { Most } \\
\text { Needed }\end{array}$ & Needed & $\begin{array}{l}\text { Weighted } \\
\text { mean } \\
\text { score }\end{array}$ & $\begin{array}{l}\text { Mean } \\
\text { score }\end{array}$ & TNI & Rank \\
\hline 1. & $\begin{array}{l}\text { Record keeping and its } \\
\text { importance }\end{array}$ & $\begin{array}{c}19 \\
(63.33 \%)\end{array}$ & $\begin{array}{c}11 \\
(36.67 \%)\end{array}$ & 79.00 & 2.63 & 87.78 & III \\
\hline 2. & $\begin{array}{l}\text { Selling management of } \\
\text { kids and its importance }\end{array}$ & $\begin{array}{c}24 \\
(80 \%)\end{array}$ & $\begin{array}{c}06 \\
(20 \%)\end{array}$ & 84.00 & 2.80 & 93.33 & II \\
\hline 3. & $\begin{array}{l}\text { Tools for profitable } \\
\text { goat farm and its } \\
\text { importance }\end{array}$ & $\begin{array}{l}28 \\
(93.33 \%)\end{array}$ & $\begin{array}{l}02 \\
(6.67 \%)\end{array}$ & 88.00 & 2.93 & 97.78 & I \\
\hline
\end{tabular}

Table 6showed that information about disease i.e. mastitis, ET, BQ, Pox, pneumonia and prevention and destruction of internal and external parasites and its importance $(\mathrm{TNI}=$
98.89) was ranked first followed by information about cutting of navel cord and its importance, diseases of goats and its home remedies $(\mathrm{TNI}=97.78)$, vaccination for 
prevention of contagious diseases and its importance $(\mathrm{TNI}=94.44)$, ethnoveterinary practices for treatment $(\mathrm{TNI}=93.33)$ respectively. These findings are in line with Jena (2018).The reason could be attributed that inadequate knowledge of the causes, symptoms and treatment of diseases results in financial burden, that's why goat entrepreneurs had required training in disease and health care management.

From table 7 it is clear that, majority of respondents perceived that training on tools for profitable goat farming $(\mathrm{TNI}=97.78)$ as most important training need followed by selling management of kids and its importance $(\mathrm{TNI}=93.33)$, record keeping and its importance $(\mathrm{TNI}=87.78)$ respectively. The possible reasons for less record keeping might be unawareness about the importance of record maintaining.

Based on the results it can be concluded that training institutions should follow a holistic approach while planning training programmes. For profit maximisation, the extension agencies should take utmost care to plan and execute training programmes as per the need and interest of the participants which in turn will help in better efficiency of training programmes.

\section{References}

1. Jena, A., Kumar , P., Mishra, K., and Ojha, S. 2018. Training needs of goat farmers: An analysis. The Pharma
Innovation Journal, 7(7): 844-847.

2. Landge, S.2004. Study of goat production practices by goat keepers of Kandhar block in Nanded district. M.V.Sc. Thesis, MAFSU, Nagpur.

3. Mirza, S. S. 2005. Human resources management, Tata McGraw-Hill publication, New Delhi, 3rd ed.: 240241

4. Nandeshwar, J.D., Landge, S. P., Banthiya, V.V., ChopadeS.S., Dhok, A.P. and Patil, D.V. 2018. Information Needs of Goat Farmers in Nagpur Division of Maharashtra. Int.J.Curr.Microbiol.App.Sci,. $\quad$ 7(11): 3123-3129. doi: https://doi.org/10.20546/ijcmas.2018.7 11.358

5. Patil, S.S. and Kokate, K.D. 2011. Training need assessment of subject matter specialists of KrishiVigyanKendras. Indian Res. J. Ext. Edu., 11(1): 18-22.

6. SA PPLPP 2011. Small ruminant rearing, product markets, opportunities and constraints. South-Asian Pro Poor Policy Programme. Retrieved from www.http://sapplpp.org/filesrepository/goodpractices/Small\%20Ru minants-Product \% 20Markets \% 20Opportunities \% 20 and \% 20Constraints.pdf

7. Tekale, M., Deshmukh, D.S., Rathod. P., Sawant, M., 2013. Training needs of goat keepers in Maharashtra. Indian Res. J Extn. Edu.,13(2):67-71.

\section{How to cite this article:}

Sireesha Pulla, R. Nithiaselvi, P. Mathialagan and P. Thilakar. 2020. Training Needs of Goat Entrepreneurs in Tamil Nadu. Int.J.Curr.Microbiol.App.Sci. 9(01): 1736-1741. doi: https://doi.org/10.20546/ijcmas.2020.901.193 